\title{
Freshwater Ascomycetes: Jahnula purpurea (Jahnulales, Dothideomycetes), a new species on submerged wood from Martinique Island, Lesser Antilles
}

\author{
Jacques Fournier', Huzefa A. Raja ${ }^{2}$, Carol A. Shearer ${ }^{3}$
}

I Las Muros, F. 09420 Rimont, France 2 University of North Carolina, Department of Chemistry and Biochemistry, 435 Sullivan Science Building, 301 McIver Street, Greensboro, North Carolina, 27412, USA 3 Department of Plant Biology, University of Illinois, Urbana, Illinois 61801, USA

Corresponding author: Huzefa A.Raja (haraja@uncg.edu, huzefaraja@gmail.com)

Academic editor: Andrew Miller | Received 1 January 2015 | Accepted 29 January 2015 | Published 9 March 2015

Citation: Fournier J, Raja HA, Shearer CA (2015) Freshwater Ascomycetes: Jahnula purpurea (Jahnulales, Dothideomycetes), a new species on submerged wood from Martinique Island, Lesser Antilles. MycoKeys 9: 29-36. doi: $10.3897 /$ mycokeys.9.4440

\begin{abstract}
Jahnula purpurea J.Fourn., Raja \& Shearer, a new species in the Jahnulales (Dothideomycetes) collected from submerged wood in a freshwater river in Martinique Island, Lesser Antilles, is described and illustrated. The characteristic features of the new species are: globose to subglobose, brownish black ascomata with broad, golden brown, subtending hyphae which stain the underlying wood purple; a peridial wall composed of large pseudoparenchymatic cells, which are textura angularis to prismatica in surface view; sparsely septate pseudoparaphyses embedded in a gel matrix; clavate to obclavate asci with a short pedicel; brown, one-septate, ellipsoidal, rough-walled ascospores without a gelatinous sheath or appendages. Unfortunately, because limited material was available from the type collection, we were unable to obtain molecular data. Jahnula purpurea is distinct from all previously described species of Jahnula in its ability to stain the wood purple and in a combination of ascomal, ascus, and ascospore size and morphology.
\end{abstract}

\section{Key words}

Aquatic fungi, Lotic, Submerged wood, Systematics, Morphology

Copyright Jacques Fournier et al. This is an open access article distributed under the terms of the Creative Commons Attribution License (CC BY 4.0), which permits unrestricted use, distribution, and reproduction in any medium, provided the original author and source are credited. 


\section{Introduction}

The genus Jahnula, typified by Jahnula aquatica (Plöttner and Kirschst.) Kirschst., is the largest genus in the Jahnulales, Dothideomycetes and currently contains 15 species (Hyde 1993; Hawksworth 1984; Hyde and Wong 1999; Pinruan et al. 2002; Raja and Shearer 2006; Raja et al. 2008; Sivichai and Boonyuen 2010; Suetrong et al. 2011). All species of Jahnula have been reported from submerged decorticated wood in freshwater habitats, mostly from tropical/subtropical habitats. Exceptions are J. aquatica, J. apiospora A. Carter, Raja \& Shearer, and J. sangamonensis Shearer \& Raja, which have been described and reported from fresh water in temperate geographical locations (Hawksworth 1984; Raja and Shearer 2006; Raja et al. 2008). Members of the Jahnulales are primarily reported from freshwater habitats, except Manglicola guatemalensis Kohlm. \& E. Kohlm, that is a mangrove species (Suetrong et al. 2010).

In this paper, we describe and illustrate a new species of Jahnula that was found on submerged wood collected from a freshwater river on Martinique Island, Lesser Antilles.

\section{Methods}

The methods for collection, morphological characterization and illustration are outlined in Fournier and Lechat (2010) and Réblová et al. (2015). Asci and hamathecia were mounted in black ink (Pelikan brand) for illustrations. Culturing was attempted, but without success. Since the fungus has been collected only from the type locality thus far and limited material was available to serve as a holotype specimen, attempts made to extract DNA and obtain molecular data from a very small number of ascomata were also unsuccessful. The holotype specimen is deposited in the Illinois Natural History Survey Fungarium (ILLS).

\section{Results}

\section{Taxonomy}

\section{Jahnula purpurea J. Fourn., Raja \& Shearer, sp. nov.}

Mycobank: MB811212

Figs 1, 2

Holotype. FWI, Martinique: Prêcheur, Anse Couleuvre, Couleuvre River, coastal rainforest, $14^{\circ} 50^{\prime} 13.05^{\prime \prime} \mathrm{N}, 61^{\circ} 13^{\prime} 22.40^{\prime \prime} \mathrm{W}$, on submerged decorticated branch, 03 Jun. 2014, J. Fournier, MJF 14016; (ILLS 72402).

Description. Ascomata 125-185 (-220) $\mu \mathrm{m}$ diam, globose to subglobose, scattered or clustered in small groups, immersed-erumpent, the base remaining immersed in the substrate, brownish black appearing black when dry, attached to subtending 

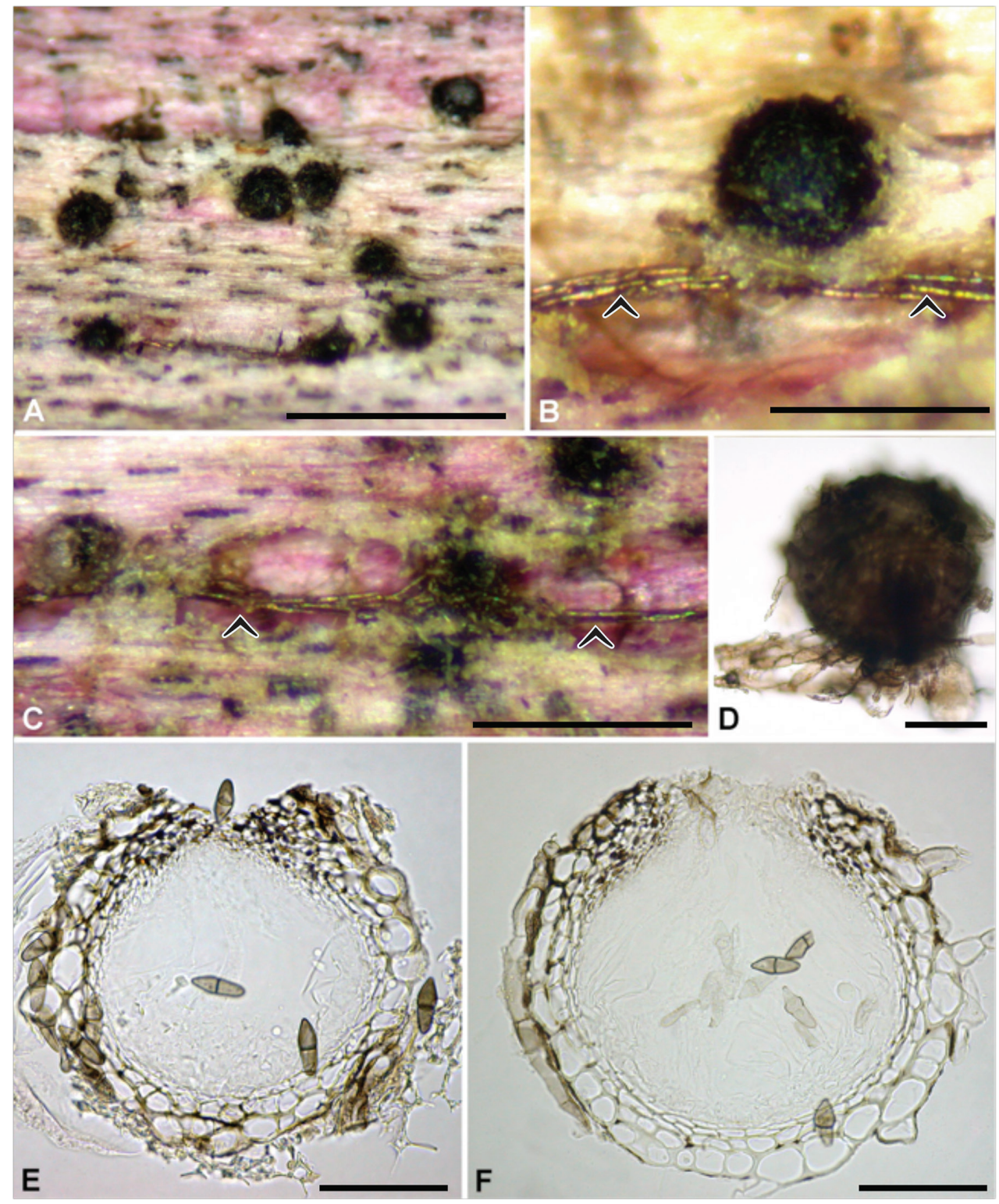

Figure I.A-F Jahnula purpurea (from the HOLOTYPE; MJF 14016, ILLS 72402). A-C Ascomata on submerged wood. Note the purple stain. Arrowheads indicate the subtending superficial hyphae on wood, which connect multiple ascomata on wood $\mathbf{D}$ Ascoma in water showing broad hyphae emerging from the base of the fruiting body $\mathbf{E}$, $\mathbf{F}$ Longitudinal section through ascoma. Note broad pseudoparenchymatic cells comprising the peridial wall. Scale bars: A, C $=500 \mu \mathrm{m} ; \mathbf{B}=1 \mathrm{~mm} ; \mathbf{D}=100 \mu \mathrm{m} ; \mathbf{E}-\mathbf{F}=20 \mu \mathrm{m}$;

golden brown hyphae 8-22 $\mu \mathrm{m}$ diam, smooth, slightly constricted at septa; hyphae form cords developing under the wood surface and linking adjacent ascomata (Fig. 1AD); wood beneath ascomata or at the periphery of the colony stained purple; ostiole 


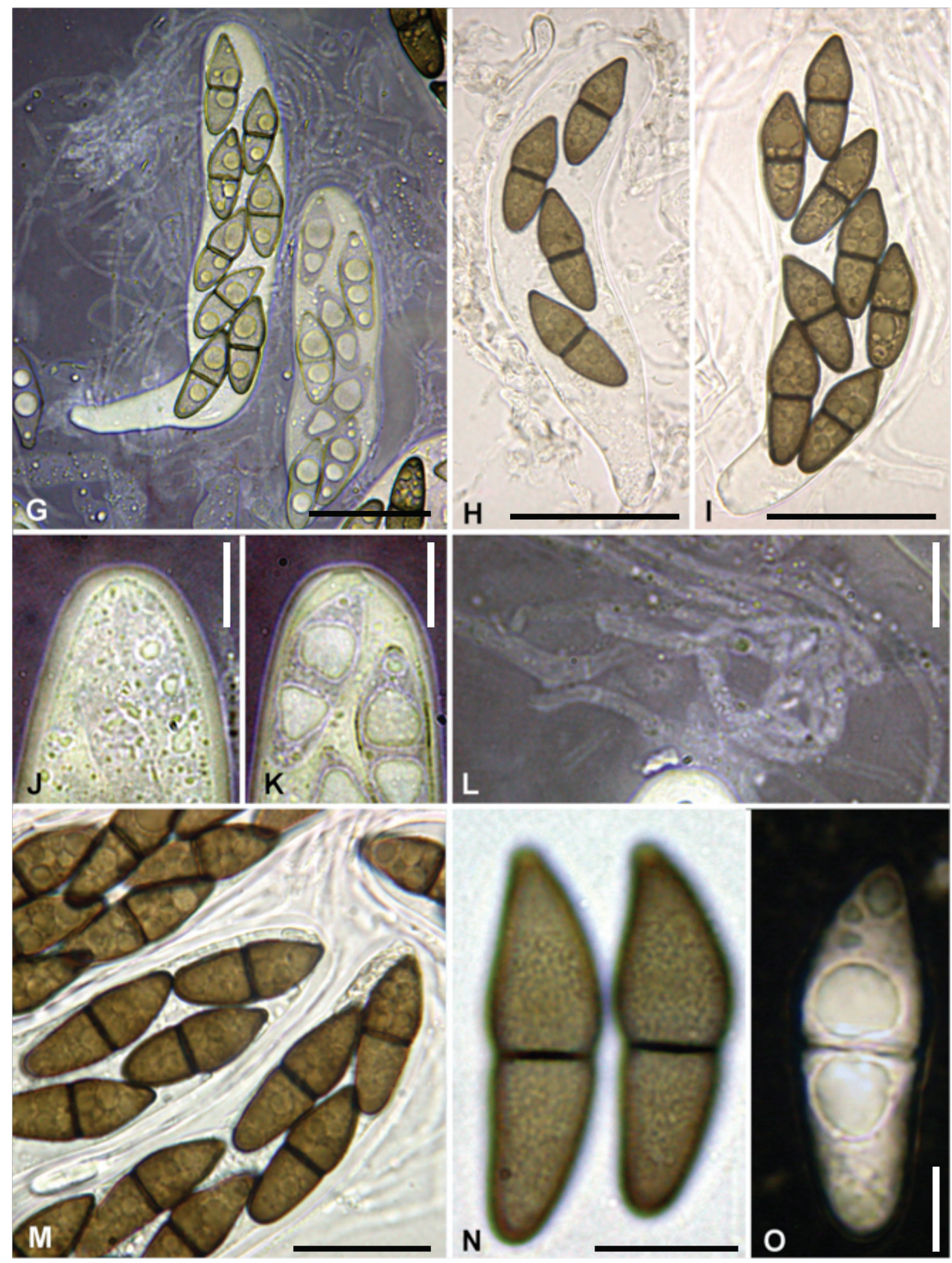

Figure 2. G-I Clavate to obclavate asci. J, K Ascus apex showing faint truncate ocular chamber $\mathbf{L}$ Pseudoparaphyses $\mathbf{M}-\mathbf{N}$ Multiguttulate brown ascospores. Note ascospores showing minutely verrucose warts forming a loose reticulate pattern $\mathbf{O}$ Immature ascospore in India ink. Scale bars: $\mathbf{G}-\mathbf{I}, \mathbf{M}=20 \mu \mathrm{m}$; $\mathbf{J}-\mathbf{L}=5 \mu \mathrm{m} ; \mathbf{N}, \mathbf{O}=10 \mu \mathrm{m}$. 
non-papillate, slightly depressed, pallid, rounded, minute, filled with hyaline periphyses (Fig. 1F). Peridium appearing roughened by protruding cells (Fig. 1B, D), 22-35 $\mu \mathrm{m}$ wide, two-layered: outermost layer textura angularis, composed of 1-2 rows of large thick-walled cells $8-18 \mu \mathrm{m}$ in their greatest dimension, extending into hyphal appendages in places (Fig. 1F), more pigmented in upper half, inwardly lined by smaller hyaline flattened cells forming a textura prismatica (Fig. 1E, F). Asci 90-98 × 22.5-25 $\mu \mathrm{m}$, bitunicate, with fissitunicate dehiscence occurring rarely, clavate to slightly obclavate, shortly pedicellate, 4-8-spored, ascospores 1-3 seriate (Fig. 2G-I); apex without (Fig. 2J) or with a faint truncate ocular chamber (Fig. 2K). Pseudoparaphyses 1-2.5 $\mu \mathrm{m}$ wide, cellular, often contorted, sparsely septate, rarely anastomosing, embedded in a gel matrix (Fig. 2G, L). Ascospores (23) 24-28 (31) $\times(7)$ 8-9 $\mu \mathrm{m}$, (mean $=26 \times 8 \mu \mathrm{m} ; \mathrm{n}=$ $60)$, ellipsoid-fusiform, 1 -septate, septum median to slightly submedian $(0.53, \mathrm{~N}=20)$, slightly constricted at the septum, upper cell wider and often apically pinched, lower cell obtusely rounded (Fig. 2H, I, M), contents densely guttulate; wall medium brown, minutely verrucose with warts partially in contact and forming a loose reticulate pattern (Fig. $2 \mathrm{~N}$ ), visible in hyaline immature ascospores; no sheath or appendages observed in aqueous nigrosin or India ink (Fig. 2O).

Etymology. From Latin "purpureus" referring to the characteristic staining of the substrate purple by this species.

Anamorph. Not known.

Known distribution. Martinique, Lesser Antilles (Known only from type locality thus far).

\section{Discussion}

Jahnula purpurea differs from all other species of Jahnula in that it stains the wood on which it grows purple. In addition, it is one of the species of Jahnula, which has minute ascomata (125-185 $\mu \mathrm{m}$ diameter). The only other species reported to have minute ascomata is Jahnula marakotii Sivichai \& Boonyeun, a species reported from a submerged wood test block of Azadirachta indica from a peat swamp in Thailand (Sivichai and Boonyeun 2010). Jahnula purpurea differs from J. marakotii in a number of morphological characters such as shape and size of asci and ascospores. The asci of $J$. purpurea are clavate to obclavate $(90-98 \times 22.5-25 \mu \mathrm{m})$, while those of $J$. marakotii are cylindrical (107.5-120 $\times 9-11.5 \mu \mathrm{m})$. The ascospores of $J$. purpurea do not possess apical appendages and are larger in size $(24-28 \times 8-9 \mu \mathrm{m})$, while those of $J$. markotii are equipped with bipolar, hyaline apical appendages and are shorter $(17.5-20 \times 5-6.5)$ in size.

Jahnula purpurea should also be compared to the type species of the genus, J. aquat$i c a$, in that the ascospores of the two species look morphologically similar at first glance. The two species are however, quite distinct. Jahnula purpurea has smaller ascomata, clavate asci, and smaller ascospores, while J. aquatica has larger ascomata, cylindrical 
asci, and larger ascospores (Hawksworth 1984; Hyde and Wong 1999; Raja and Shearer 2006). In addition, J. purpurea stains its wood substrate purple (Fig. 1A-C), which has never been reported for substrates on which J. aquatica occurs (Hawksworth 1984; Raja and Shearer 2006). Another species of Jahnula that is morphologically similar to $J$. purpurea in overall ascomata and ascospore morphology includes J. australiensis. On closer examination, however, the species are quite distinct. Jahnula purpurea stains subtending wood purple, a character not observed in J. australiensis; the asci in J. purpurea are clavate to obclavate, while those of $J$. australiensis are cylindrical; the ascospores of both the species are some what similar in size (24-28 $\times 8-9 \mu \mathrm{m}$ in J. purpurea vs. 19-30 $\times 6-8 \mu \mathrm{m}$ in $J$. australiensis) but those of $J$. purpurea are slightly smaller and wider.

Several species of freshwater ascomycetes in the family Amniculicolaceae are capable of staining underlying wood substrates purple (Zhang et al. 2009a; Zhang et al. 2009b; Zhang et al. 2012), a characteristic similar to J. purpurea. However, Amniculicolaceae is phylogenetically related to the Pleosporales, while based on morphological data presented herein J. purpurea belongs to the Jahnulales (Pang et al. 2002; Campbell et al. 2007; Suetrong et al. 2011).

In addition, species of Massariosphaeria such as M. phaeospora (E. Müll.) Crivelli has the ability to stain wood purple (Zhang et al. 2012). Lophiostoma purpurascens (K.D. Hyde \& Aptroot) Aptroot \& K.D. Hyde reported from submerged wood in freshwater habitats in Australia and Papua New Guinea also stains wood purple (Hyde and Aptroot 1998; Hyde et al. 2002). However M. phaeospora, and L. purpurascens are phylogenetically unrelated to the Amniculicolaceae (Zhang et al. 2012). Another recently described species, Massariosphaeria fridae M. Spooren stains its substrate (dead stalks of Alisma plantago-aquatica) red (Spooren 2007). This suggests that unrelated freshwater Dothideomycetes have the ability to stain the vicinity of their substrate red or purple. It would be interesting to study the secondary metabolites from these taxa in the future to understand if there is an underlying ecological significance to the production of bright pigments by species of both terrestrial and freshwater ascomycetes within the Dothideomycetes. Additional collections and molecular sequence data from J. purpurea in the future would certainly shed light on the hypothesis of purple pigment being a true phylogenetic informative character at the family-level within the Dothideomycetes as suggested by Zhang et al. (2012). The production of purple pigment on wood by J. purpurea suggests that pigment production might be a case of convergent evolution that could be functionally significant within the Dothideomycetes. It is also likely that different colors might be characteristic of different phylogenetic clades and might have similar or dissimilar ecological functions.

\section{Acknowledgements}

HAR would like to thank Dr. Nicholas H. Oberlies, UNCG for logistics provided to complete this manuscript. We also thank the reviewers for their valuable comments. 


\section{References}

Campbell J, Ferrer A, Raja HA, Sivichai S, Shearer CA (2007) Phylogenetic relationships among taxa in the Jahnulales inferred from $18 \mathrm{~S}$ and $28 \mathrm{~S}$ nuclear ribosomal DNA sequences. Canadian Journal of Botany 85: 873-882. doi: 10.1139/B07-080

Fournier J, Lechat C (2010) Phomatospora luteotingens sp. nov., a new aquatic species of Phomatospora from France and Spain. Mycosphere 1:39-43.

Hawksworth DL (1984) Observations on Jahnula Kirschst., a remarkable aquatic pyrenomycete. Sydowia 37: 43-46.

Hyde KD (1993) Tropical Australian freshwater fungi. V. Bombardia sp., Jahnula australiensis sp. nov., Savoryella lignicola and S. aquatica sp. nov. Australian Systematic Botany 6: 161-167. doi:10.1071/SB9930161

Hyde KD, Aptroot A (1998) Tropical freshwater species of the genera Massarina and Lophiostoma (ascomycetes). Nova Hedwigia 66: 489-502.

Hyde KD, Wong SW (1999) Tropical Australian Freshwater Fungi. XV. The ascomycete genus Jahnula, with five new species and one new combination. Nova Hedwigia 68: 489-509.

Hyde KD, Wong WSW, Aptroot A (2002) Marine and estuarine species of Lophiostoma and Massarina. In: Hyde KD (Ed.) Fungi in Marine Environments. Fungal Diversity Research Series 7: 93-109.

Pang KL, Abdel-Wahab MA, Sivichai S, El-Sharouney HM, Jones EBG (2002) Jahnulales (Dothideomycetes, Ascomycota): A new order of lignicolous freshwater ascomycetes. Mycological Research 106: 1031-1042. doi: 10.1017/S095375620200638X

Pinruan U, Jones EBG, Hyde KD (2002) Aquatic fungi from peat swamp palms: Jahnula appendiculata sp. nov. Sydowia 54: 242-247.

Raja HA, Carter A, Platt HW, Shearer CA (2008) Freshwater ascomycetes: Jahnula apiospora (Jahnulales, Dothideomycetes), a new species from Prince Edward Island, Canada. Mycoscience 49: 326-328. doi: 10.1007/s10267-008-0428-2

Raja HA, Shearer CA (2006) Jahnula species from North and Central America, including three new species. Mycologia 98: 319-332.

Réblová M, Fournier J, Štěpánek V (2015) Pisorisporiales, a new order of aquatic and terrestrial fungi for Achroceratosphaeria and Pisorisporium gen. nov. in the Sordariomycetes. Persoonia 34: 40-49. doi: 10.3767/003158515X685544

Sivichai S, Boonyeun N (2010) Jahnula morakotii sp. nov. and J. appendiculata from a peat swamp in Thailand. Mycotaxon 112: 475-481. doi: 10.5248/112.475

Spooren M (2007) Massariosphaeria fridae, a new freshwater ascomyete. Persoonia 19: 261-263

Suetrong S, Sakayroj J, Phongpaichit S, Jones EBG (2010) Morphological and molecular characteristics of a poorly known marine ascomycete, Manglicola guatemalensis (Jahnulales: Pezizomycotina; Dothideomycetes, Incertae sedis): new lineage of marine ascomycetes. Mycologia 102: 83-92 . doi: 10.3852/07-147

Suetrong S, Boonyeun N, Pang KL, Ueapattanakit J, Klaysuban A, Sri-Indrasutdhi V, Sivichai S, Jones EBG (2011) A taxonomic revision and phylogenetic reconstruction of the Jahnulales (Dothideomycetes), and the new family Manglicolaceae. Fungal Diversity 51: 163-188. doi: 10.1007/s13225-011-0138-5 
Zhang Y, Fournier J, Crous PW, Pointing SB, Hyde KD (2009a) Phylogenetic and morphological assessment of two new species of Amniculicola and their allies (Pleosporales). Persoonia 23: 48-54. doi: 10.3767/003158509X472187

Zhang Y, Schoch CL, Fournier J, Crous PW, de Gruyter J, Woudenberg JHC, Hirayama K, Tanaka K, Pointing SB, Spatafora JW et al. (2009b) Multi-locus phylogeny of Pleosporales: A taxonomic, ecological and evolutionary re-evaluation. Studies in Mycology 64: 85-102. doi: 10.3114/sim.2009.64.04

Zhang Y, Crous PW, Schoch CL, Hyde KD (2012) Pleosporales. Fungal Diversity 53: 1-221. doi: $10.1007 / s 13225-011-0117-x$ 